Article

\title{
Effect of Elatol, Isolated from Red Seaweed Laurencia dendroidea, on Leishmania amazonensis
}

Adriana Oliveira dos Santos ${ }^{1}$, Phercyles Veiga-Santos ${ }^{2}$, Tânia Ueda-Nakamura ${ }^{2}$, Benedito Prado Dias Filho ${ }^{1,2}$, Daniela Bueno Sudatti ${ }^{3}$, Éverson Miguel Bianco ${ }^{4}$, Renato Crespo Pereira ${ }^{3,4}$ and Celso Vataru Nakamura ${ }^{1,2, *}$

1 Programa de Pós-graduação em Microbiologia, Universidade Estadual de Londrina, Rodovia Celso Garcia Cid, PR 445, Km 380, CEP 86051-990, Campus Universitário, Londrina, Paraná, Brazil; E-Mails: oi_dri@hotmail.com (A.O.S.); bdpfilho@uem.br (B.P.D.F.)

2 Programa de Pós-graduação em Ciências Farmacêuticas, Laboratório de Inovação Tecnológica no Desenvolvimento de Fármacos e Cosméticos, Bloco B-08, Universidade Estadual de Maringá, Av. Colombo 5790, CEP 87020-900, Maringá, Paraná, Brazil;

E-Mails: phercyles@gmail.com (P.V.-S.); tunakamura@uem.br (T.U.-N.)

3 Departamento de Biologia Marinha, Universidade Federal Fluminense, Caixa Postal 100644, CEP 24001-970, Niterói, Rio de Janeiro, Brazil; E-Mails: dbsudatti@gmail.com (D.B.S.); egbrecp@vm.uff.br (R.C.P.)

4 Programa de Pós-graduação em Química Orgânica, Universidade Federal Fluminense, Outeiro de São João Baptista, s/n, CEP 24.020-150, Niterói, Rio de Janeiro, Brazil;

E-Mail: ebianco@ chemist.com (É.M.B.)

* Author to whom correspondence should be addressed; E-Mail: cvnakamura@ gmail.com; Tel.: +55-44-3011-5012; Fax: +55-44-3011-4860.

Received: 9 September 2010; in revised form: 14 October 2010 / Accepted: 22 October 2010 / Published: 29 October 2010

Abstract: In the present study, we investigated the antileishmanial activity of sesquiterpene elatol, the major constituent of the Brazilian red seaweed Laurencia dendroidea (Hudson) J.V. Lamouroux, against L. amazonensis. Elatol after $72 \mathrm{~h}$ of treatment, showed an $\mathrm{IC}_{50}$ of $4.0 \mu \mathrm{M}$ and $0.45 \mu \mathrm{M}$ for promastigote and intracellular amastigote forms of $L$. amazonensis, respectively. By scanning and transmission electron microscopy, parasites treated with elatol revealed notable changes compared with control cells, including: pronounced swelling of the mitochondrion; appearance of concentric membrane structures inside the organelle; destabilization of the plasma membrane; and formation of membrane structures, apparently an extension of the endoplasmic reticulum, which is suggestive of an autophagic process. A cytotoxicity assay showed that the action 
of the isolated compound is more specific for protozoa, and it is not toxic to macrophages. Our studies indicated that elatol is a potent antiproliferative agent against promastigote and intracellular amastigote forms, and may have important advantages for the development of new anti-leishamanial chemotherapies.

Keywords: antileishmanial activity; Leishmania amazonensis; Laurencia dendroidea; elatol

\section{Introduction}

Leishmania amazonensis, a flagellated protozoan parasite, is the causative agent of human cutaneous leishmaniasis. In this infectious disease, a high proportion of cases evolve to severe anergic diffuse cutaneous leishmaniasis, which is severely debilitating and disfiguring [1,2]. Because of the devastating consequences to the patient, it is recognized as a special public health problem [3]. Cutaneous leishmaniasis is endemic in 88 countries on five continents, with 1-1.5 million cases reported yearly worldwide [4,5]. Poor nutrition, infection, and other stresses predispose patients to increased morbidity and mortality. Moreover, cases of Leishmania and human immunodeficiency virus coinfection have recently increased [6,7]. No vaccines for preventing infection are currently available $[8,9]$.

Pentavalent antimonial compounds, sodium stiboglucanate (Pentostam), and meglumine antimoniate (Glucantime), have been recommended as the first line of drugs in the treatment of cutaneous leishmaniasis for 50 years. However, these substances cause toxic effects, including nausea, vomiting, diarrhea, skin eruptions, headache, dizziness, cardiac arrhythmia, and hypotension [10-12]. In cases of resistance, amphotericin B and Pentamidine are the main alternative drugs, but their frequent and severe side effects limit their use. There is an urgent need for new and more efficient therapies for leishmaniasis.

Elatol was isolated from Laurencia elata for the first time by Sims et al. [13]. Various species of Laurencia (order Ceramiales, family Rhodomeleceae) also produce the sesquiterpene elatol as its major secondary metabolite [14-19]. Several studies have shown that elatol plays important roles in ecological interactions, such as antiherbivore activity and potential defense against infection by microorganisms [13-16]. Recent studies have shown that elatol can be synthesized in the laboratory [20,21]. Therefore, this study investigated the antileishmanial activity of elatol isolated from the Brazilian red seaweed Laurencia dendroidea against the promastigote and intracellular amastigote forms of L. amazonensis. Additionally, we used electron microscopy techniques to evaluate the effect of elatol on the morphology and ultrastructure of the parasite.

\section{Results and Discussion}

Marine algae have been used in traditional remedies in Asian countries including China, Japan, and Korea [22]. Species of Laurencia (order Ceremiales, family Rhodomeleceae) have proved to be a rich source of halogenated secondary metabolites, predominantly sesquiterpenes, diterpenes, and $\mathrm{C}_{15}$ non terpenoids [23-25]. Probably, these halogenated metabolites defend against marine herbivores and 
infection by microorganisms [23,26-28]. Various studies have reported that seaweeds have shown important biological activities, including antibacterial, antifungal, antileishmanial, antitrichomonal, antihelmintic, antiviral, antipyretic, analgesic, anti-inflammatory, antioxidative, and anticoagulant $[15,20,22,25,28-36]$. In the present study, we assessed the antileishmanial activity of sesquiterpene elatol, the major constituent of the Brazilian red seaweed L. dendroidea (Hudson) J.V. Lamouroux, against L. amazonensis. The physical and spectroscopic properties of the sesquiterpene elatol (Figure 1) were identical with data previously reported by König and Wright [14].

Figure 1. The chemical structure of elatol.

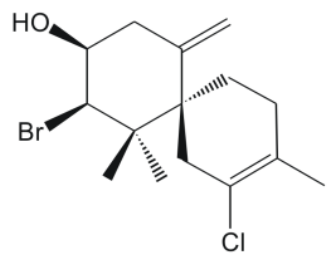

Elatol showed a dose-dependent antileishmanial activity against the promastigote forms. Concentrations of $4.0 \pm 0.3 \mu \mathrm{M}$ and $7.5 \pm 0.5 \mu \mathrm{M}$ of elatol induced $50 \%$ and $90 \%$ growth inhibition on L. amazonensis, respectively, after $72 \mathrm{~h}$ of treatment (Figure 2).

Figure 2. Effect of elatol against promastigote forms of L. amazonensis.

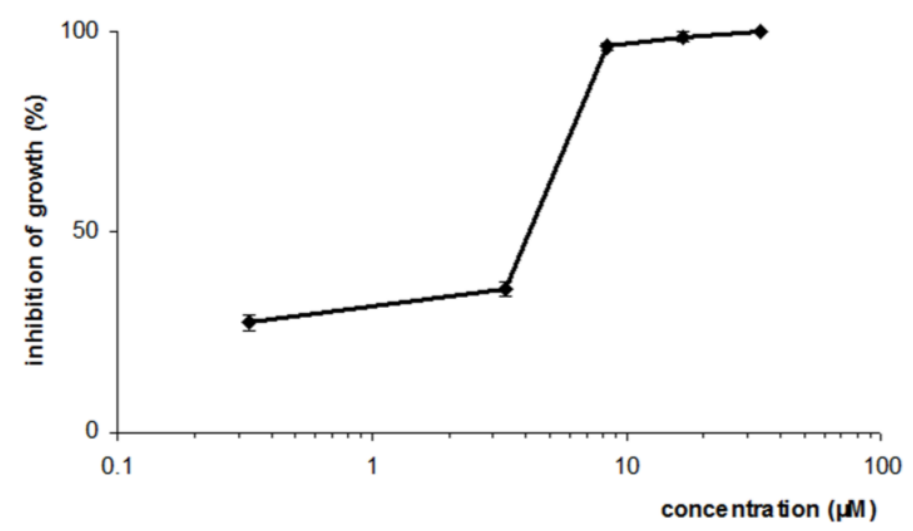

Figure 3 shows the effects of the elatol on the L. amazonensis-macrophage interaction. When the parasites were treated with elatol, a dose-dependent decrease of intracellular amastigotes was observed. The survival index was calculated as 392.0 for $0.15 \mu \mathrm{M} ; 325.0$ for $0.30 \mu \mathrm{M}$; and 230.0 for $1.5 \mu \mathrm{M}$. These results correspond to rates of inhibition of survival as high as 57,65 , and $75 \%$, respectively. The $\mathrm{IC}_{50}$ for the intracellular amastigote form was $0.45 \mu \mathrm{M}$. The intracellular forms are a great challenge in the treatment of leishmaniasis. All the results were significant at $p \leq 0.05$ compared to the control group, by Student's $t$-test. Amphotericin B showed $\mathrm{IC}_{50}$ of $0.06 \mu \mathrm{M}$ and $0.31 \mu \mathrm{M}$ against the promastigote and intracellular amastigote forms, respectively. Elatol was also evaluated for its potential toxic effects on macrophage strain J774G8. When macrophages were treated with elatol, the $50 \%$ cytotoxic concentration $\left(\mathrm{CC}_{50}\right)$ was $1.4 \mu \mathrm{M}$. The toxicity to the macrophage and the activity against protozoa were compared by using the selectivity index (SI) (ratio: $\mathrm{CC}_{50}$ macrophage J774G8 cells/IC 50 protozoa). The observed SI for the intracellular amastigote forms was 3.0 times less toxic to the macrophage than to the protozoa. 
Figure 3. Survival index of $L$. amazonensis within peritoneal macrophage cells treated with elatol. * Significant difference of each group from the control $(\mathrm{p}<0.05)$.

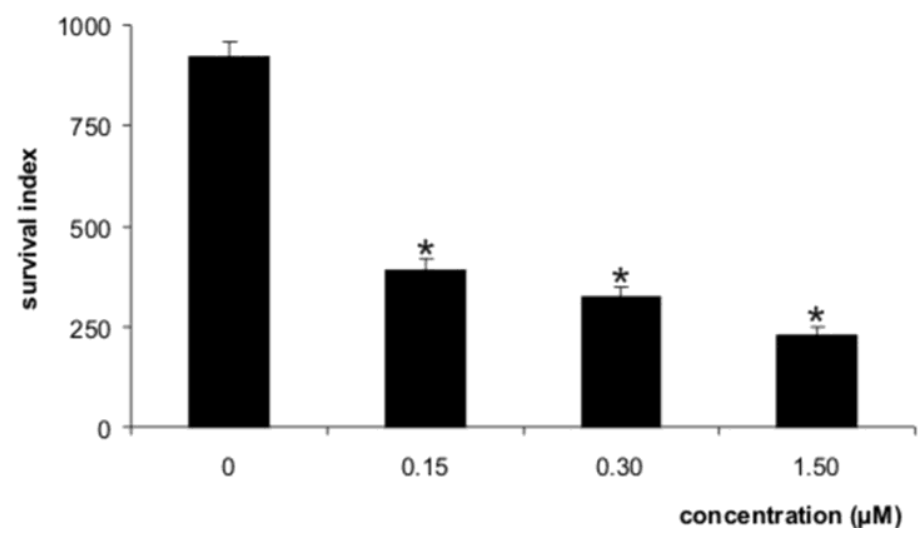

By scanning electron microscopy, promastigote forms treated with elatol revealed notable morphological changes compared with the control cells (Figure 4A). There were changes in size and shape (Figure 4B, C, D, and F). In addition, cells showed rupture of the plasma membrane with loss of their contents (Figure 4C-F) and cell shrinkage (Figure 4F).

Figure 4. Scanning electron microscopy of promastigote forms of L. amazonensis treated with elatol after incubation for $48 \mathrm{~h}$ at $25{ }^{\circ} \mathrm{C}$. (A) Control; (B-F) Parasites after treatment with $\mathrm{IC}_{50}$ of elatol. Bars $=1 \mu \mathrm{m}$.
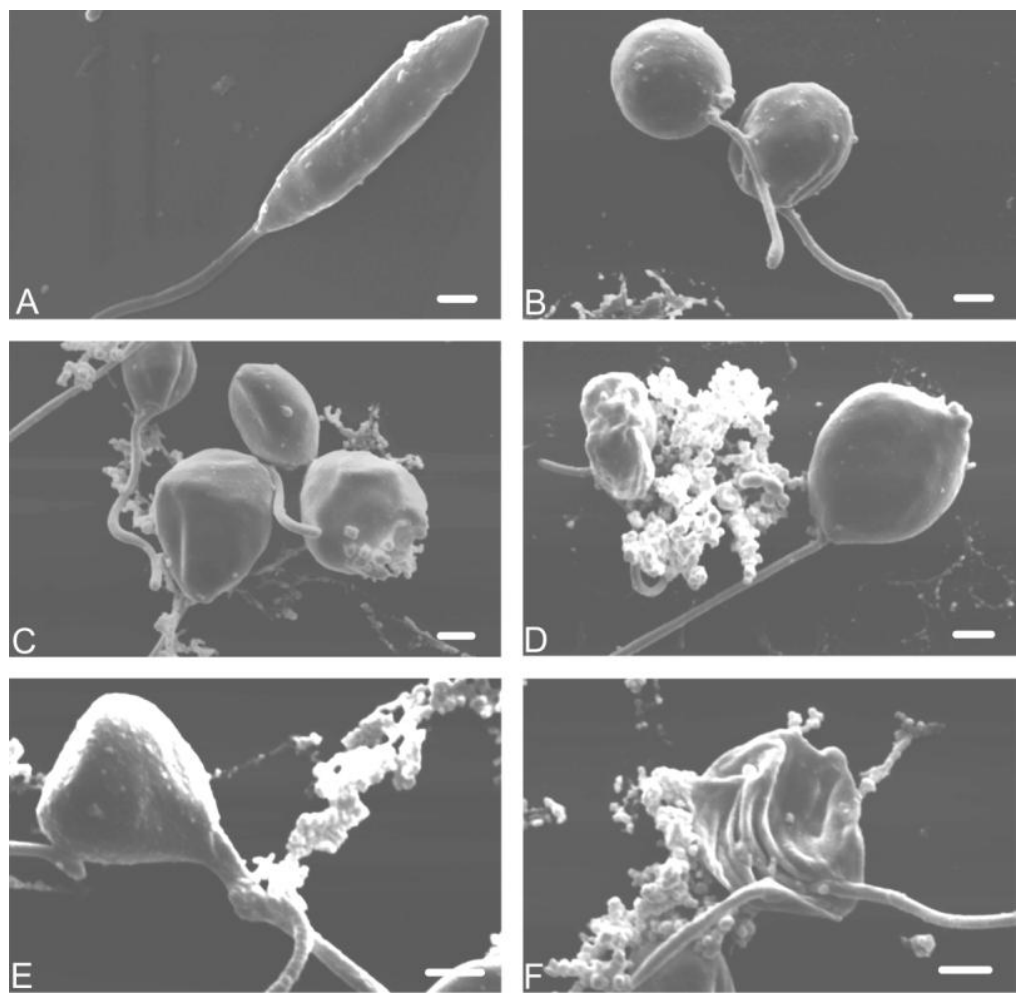

Photomicrographs from transmission electron microscopy are shown in Figure 5. Control parasites showed no changes in the plasma membrane, and an apparently normal ultrastructure (Figure 5A). In promastigote forms, the treatment with elatol led to a pronounced swelling of the mitochondrion and the appearance of concentric membrane structures inside the organelle (Figure 5C), destabilization of 
the plasma membrane (Figure 5D), and autophagic vacuoles (Figure 5B). The treated cells also formed membrane structures, apparently an extension of the endoplasmic reticulum, which is suggestive of an autophagic process (Figure 5C). A similar structure was not seen in untreated cells. We also observed the effects of elatol on intracellular amastigote forms. Peritoneal macrophages were infected in multiples of 10 promastigotes per host cell, and were incubated at $37{ }^{\circ} \mathrm{C}$ in $5 \% \mathrm{CO}_{2}$ atmosphere. After $24 \mathrm{~h}$, the infected macrophages were treated with elatol. Figure 5E shows several intracellular amastigotes in peritoneal macrophages. In the ultrastructural evaluation of treated amastigotes, the most prominent effect was swollen mitochondria (Figure 5E, F and G).

Figure 5. Ultrastructural effect of elatol after incubation for $48 \mathrm{~h}$ at $25^{\circ} \mathrm{C}$ on promastigote and intracellular amastigote forms of L. amazonensis, observed by transmission electron microscopy. (A) Promastigote control; (B-D) Promastigote treated with $\mathrm{IC}_{50}$ of elatol; $(\mathbf{E}-\mathbf{H})$ Intracellular amastigote forms treated with $\mathrm{IC}_{50}$ of elatol. Elatol treatment led to swelling of the mitochondria (white arrow), autophagic vacuoles (black stars), appearance of concentric membrane structures inside the organelle (asterisk), destabilization of the plasma membrane (arrowhead), extension of the endoplasmic reticulum (two arrows), and intracellular amastigotes in peritoneal macrophages (white star). n: nucleus; f: flagellum; fp: flagellar pocket; $\mathrm{k}$ : kinetoplast; $\mathrm{m}$ : mitochondrion; Bars $=1 \mu \mathrm{m}$.

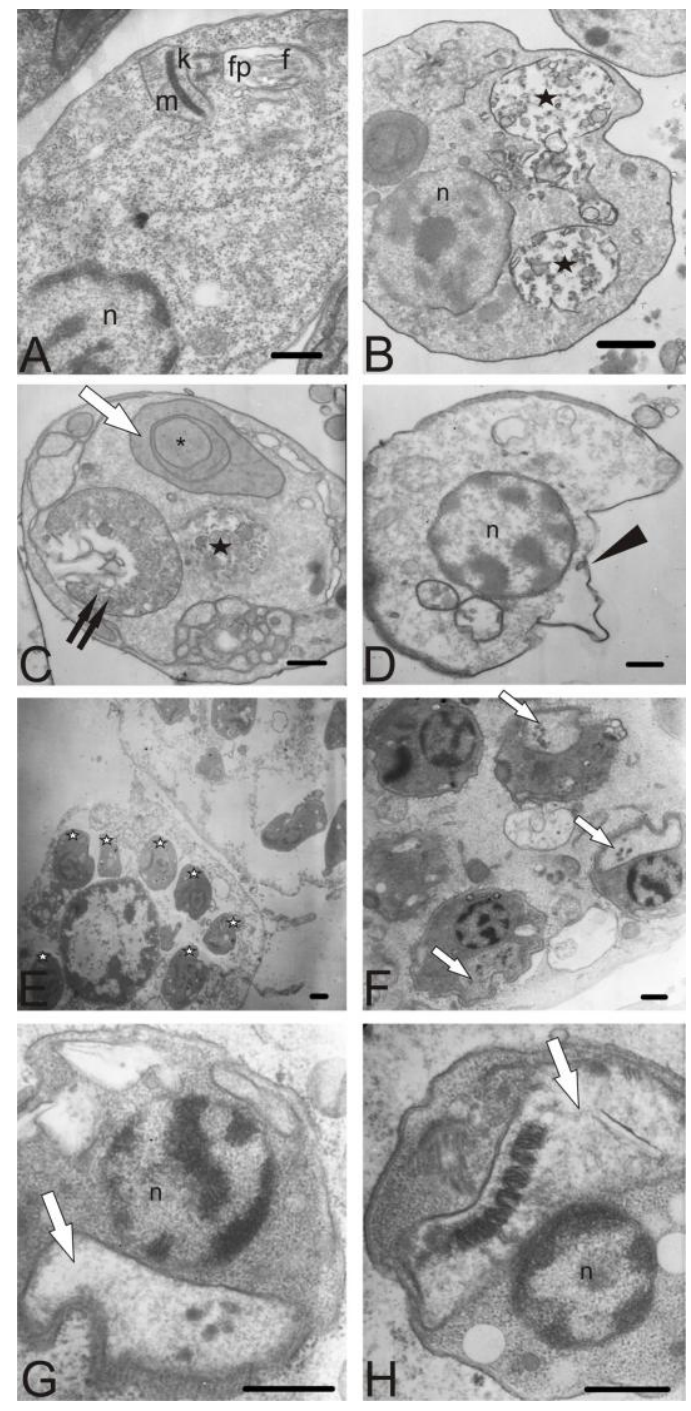


Interestingly, a similar mechanism is seen during treatment with ergosterol biosynthesis inhibitors. Lazardi et al. [37] showed that epimastigote and amastigote forms of Trypanosoma cruzi treated with the minimum growth-inhibitory concentration of ICI 195,739 $(0.1 \mu \mathrm{M})$ displayed almost immediate ultrastructural alterations, consisting of membrane lesion, intense swelling of the mitochondrion with loss of the inner membrane, and changes in the matrix electron density, as well as the appearance of autophagic vacuoles. Similar results have been reported by Rodrigues et al. [38] in L. amazonensis promastigotes treated with azasterols, known inhibitors of the $\Delta^{24(25)}$-sterol methyltransferase, showing several alterations in the mitochondrion structure such as disorganization of the internal membranes and an intense and evident mitochondrial swelling with loss of the matrix content. This is in agreement with Lorente et al. [39], who found similar alterations when parasites were treated with azasterols. These compounds were shown to have ultrastructural effects on L. amazonensis promastigote membranes, including the plasma and mitochondrial membranes, and the endoplasmic reticulum. In addition, Rodrigues et al. [40] described the effects of sterol methenyl transferase inhibitors (SMTI), essential enzymes for sterol biosynthesis, on promastigote and axenic amastigote forms of L. amazonensis. Ultrastructural alterations in treated cells were observed mainly in the mitochondrion, which displayed intense swelling and reduced electron density of the matrix, with marked changes in the inner mitochondrial membranes.

\section{Experimental Section}

\subsection{Plant material and extraction procedures}

Specimens of $L$. dendroidea were collected by hand during low tide, in the midlittoral zone on the

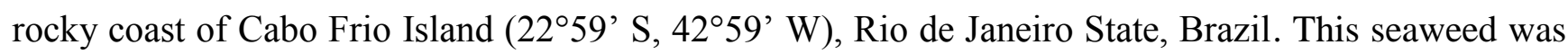
previously described as L. obtusa, but through molecular techniques, it was recently identified as L. dendroidea [41]. The seaweed was stored in plastic bags and chilled on ice during transport to the laboratory. The specimens of $L$. dendroidea used in this study were identified by Dr. Mutue Toyota Fujii, and voucher specimens were deposited in the herbaria SP, Instituto de Botânica, São Paulo State, Brazil (SP number: 399789). L. dendroidea was dried in the dark at room temperature.

\subsection{Extraction procedures and elatol isolation}

The air-dried algal material (300.0 g) giving $50 \mathrm{mg}$ of elatol was successive and exhaustively extracted in $n$-hexane at room temperature for 15 days. The $n$-hexane crude extract (HE) was evaporated to dryness on a rotary evaporator at low temperature $\left(<50{ }^{\circ} \mathrm{C}\right)$, yielding $3.64 \mathrm{~g}$ of a dark green extract containing the sesquiterpene elatol, which was detected as brown spot on TLC plates after spraying with a solution of ceric sulphate and sulfuric acid $\left(2.1 \mathrm{~g} \mathrm{of} \mathrm{Ce}_{2}\left(\mathrm{SO}_{4}\right)_{3} \cdot 4 \mathrm{H}_{2} \mathrm{O} ; 21 \mathrm{~mL}\right.$ of $\mathrm{H}_{2} \mathrm{SO}_{4}$ and $300 \mathrm{~mL}$ of $\left.\mathrm{H}_{2} \mathrm{O}\right)$, followed by heating at $100{ }^{\circ} \mathrm{C}$ for $3 \mathrm{~min}$. An aliquot of $\mathrm{HE}(0.35 \mathrm{~g})$ was submitted to preparative thin layer chromatography (PTLC) (Merck, silica gel $60 \mathrm{~F}_{254}, 20 \times 20 \mathrm{~cm}$, mobile phase: $n$-hexane/ethyl acetate $8: 2)$, to afford a yellowish oil (50 mg) which was identified as the sesquitepene elatol. The purity was confirmed by TLC ( $\mathrm{Rf}=0.45)$, using $n$-hexane/AcOEt 8:2 as mobile phase, and by ${ }^{1} \mathrm{H}-\mathrm{NMR}$ spectroscopy (300 MHz). 


\subsection{Spectroscopic data}

The physical and spectroscopic properties of the isolated elatol were identical to those previously reported by König and Wright [42].

\subsection{Parasite and cell culture}

Promastigote forms of L. amazonensis (MHOM/BR/75/Josefa strain) were maintained by weekly transfers in Warren's medium [43] supplemented with 10\% heat-inactivated fetal bovine serum (FBS) at $25{ }^{\circ} \mathrm{C}$ in a tissue flask. The macrophage lineage (J774G8) was maintained in tissue flasks in RPMI 1640 medium (Gibco Invitrogen Co., Grand Island, New York, U.S.) with L-glutamine and supplemented with $10 \%$ inactivated fetal bovine serum at $37{ }^{\circ} \mathrm{C}$ in a $5 \% \mathrm{CO}_{2}$-air mixture.

\subsection{Antileishmanial activity}

L. amazonensis promastigotes $\left(1 \times 10^{6}\right.$ parasites $\left./ \mathrm{mL}\right)$ were inoculated in a 24 -well plate containing Warren's medium supplemented with $10 \%$ inactivated fetal bovine serum with different concentrations of elatol $(0.1$ to $100 \mu \mathrm{M})$, and incubated at $25{ }^{\circ} \mathrm{C}$ for $72 \mathrm{~h}$. The cell density for each concentration was determined by counting in a hemocytometer (Improved Double Neubauer). Amphotericin B was used as a positive control. Controls containing 1.0\% dimethyl sulfoxide (DMSO; Sigma Chemical Co., St. Louis, Missouri, U.S.) and medium alone were also included. The results were expressed by $\mathrm{IC}_{50}$ (concentration that inhibited 50\% parasite growth).

\subsection{Activity against intracellular amastigotes}

After $72 \mathrm{~h}$ of inoculation of $5 \%$ thioglycolate medium, resident peritoneal cells from the BALB/c mice were harvested in RPMI 1640 medium (Gibco Invitrogen Corporation, New York, U.S.) pH 7.6. Cells were plated on coverslips (diameter $13 \mathrm{~mm}$ ) in 24-well plates and allowed to adhere for $24 \mathrm{~h}$ at $37{ }^{\circ} \mathrm{C}$ in $5 \% \mathrm{CO}_{2}$ atmosphere. Macrophages were infected in multiples of 10 promastigotes per host cell and were incubated at $37{ }^{\circ} \mathrm{C}$ in $5 \% \mathrm{CO}_{2}$ atmosphere. After $24 \mathrm{~h}$, infected macrophages were treated with different concentrations of elatol $(0.15$ to $1.50 \mu \mathrm{M})$. Next, the monolayers were washed with PBS at $37{ }^{\circ} \mathrm{C}$, fixed in methanol, and stained with Giemsa. The number of amastigotes was determined by counting at least 200 macrophages in duplicate cultures, and the results were expressed as the survival index. The survival index was obtained by multiplying the percentage of infected macrophages by the number of amastigotes per infected macrophage.

\subsection{Cytotoxicity assay}

Adherent J774G8 macrophage cells in the logarithmic growth phase were suspended to yield $10^{5}$ cells/mL in RPMI 1640 medium supplemented with $10 \% \mathrm{FBS}$, and added to each well in 96-well microtiter plates. The plates were incubated in a $5 \% \mathrm{CO}_{2}$-air mixture at $37{ }^{\circ} \mathrm{C}$ to obtain confluent cell growth. After $24 \mathrm{~h}$, the medium was removed and the cells were treated with elatol $(0.1$ to $100 \mu \mathrm{M})$. Control wells without elatol were included. The plates were incubated in a $5 \% \mathrm{CO}_{2}$-air mixture at $37{ }^{\circ} \mathrm{C}$ for $48 \mathrm{~h}$. The cultures were then fixed with $10 \%$ trichloroacetic acid for $1 \mathrm{~h}$ at $4{ }^{\circ} \mathrm{C}$, stained for 
30 min with $0.4 \%$ sulforhodamine $B$ (SRB) in $1 \%$ acetic acid and subsequently washed five times with deionized water. Bound SRB was solubilized with $200 \mu \mathrm{L} 10 \mathrm{mM}$ unbuffered Tris-base solution. Absorbance was read in a 96-well plate reader (BIO-TEK Power Wave XS) at $530 \mathrm{~nm}$. Dose-response curves were plotted (values expressed as percentage of control optical density) and $\mathrm{CC}_{50}$ values (50\% cytotoxicity concentration) were estimated by regression analysis.

\subsection{Electron microscopy}

Promastigote and intracellular amastigote forms were treated with $\mathrm{IC}_{50}$ of elatol at $25{ }^{\circ} \mathrm{C}$ for 24 and $48 \mathrm{~h}$, respectively. The parasites were fixed in $2.5 \%$ glutaraldehyde in $0.1 \mathrm{M}$ cacodylate buffer, $\mathrm{pH}$ 7.2. For transmission electron microscopy, cells were postfixed for $40 \mathrm{~min}$ in a solution containing $1 \% \mathrm{OsO}_{4}$ and $0.8 \%$ potassium ferrocyanide in $0.1 \mathrm{M}$ cacodylate buffer, washed in the same buffer, dehydrated in acetone, and embedded in Epon. Ultrathin sections were stained with uranyl acetate and lead citrate, and were observed in a Zeiss 900 electron microscope. For observation by scanning electron microscope, promastigotes were placed on a specimen support with poly-L-lysine, dehydrated in graded ethanol, critical-point dried in $\mathrm{CO}_{2}$, coated with gold, and observed in a Shimadzu SS 550 SEM.

\subsection{Statistical analysis}

The means and standard deviations were determined from at least three experiments. All tests were done in duplicate. Statistical analysis was performed with the program GraphPad Prism 4 (GraphPad Software, San Diego, California, U.S.). Student's $t$ test was applied, and a $p$ value less than 0.05 was regarded as significant.

\section{Conclusions}

Our studies indicated that elatol is a potent antiproliferative agent against promastigote and intracellular amastigote forms of L. amazonensis, and induced notable changes in the ultrastructure of the mitochondrion of the parasite. Laboratory synthesis and the possibility of modifying the chemical structure of elatol may lead to important advances in the development of new anti-leishmanial chemotherapies. More in vitro and in vivo studies will be carried out to increase understanding of the mode of action of this drug and its future utilization in the treatment of leishmaniasis.

\section{Acknowledgements}

This study was supported through grants from Conselho Nacional de Desenvolvimento Científico e Tecnológico (CNPq), Coordenação de Aperfeiçoamento de Pessoal de Nível Superior (CAPES), Financiadora de Estudos e Projetos (FINEP), Programa de Núcleos de Excelência (PRONEX/Fundação Araucária).

\section{References}

1. Murray, H.W.; Berman, J.D.; Davies, C.R.; Saravia, N.G. Advances in leishmaniasis. Lancet 2005, 366, 1561-1577. 
2. Bailey, M.S.; Lockwood, D.N.J. Cutaneous leishmaniasis. Clin. Dermatol. 2007, 25, 203-211.

3. Desjeux, P. Global control and leishmania HIV co-infection. Clin. Dermatol. 1999, 17, 317-325.

4. Blum, J.; Desjeux, P.; Schwartz, E.; Beck, B.; Hatz. C. Treatment of cutaneous leishmaniasis among travellers. J. Antimicrob. Chemother. 2004, 53, 158-166.

5. World Health Organization. Leishmaniasis: Disease burden and epidemiological trends. Special Programme for Research and Training in Tropical Diseases. WHO: Geneva, Switzerland, 2002. Available online: http://www.who.int/tdr/diseases/leish/files/direction.pdf (accessed on 10 March 2010).

6. Fernández-Guerrero, M.L.; Robles, P.; Rivas, P.; Mójer, F.; Muniz, G.; Górgolas, M. Visceral leishmaniasis in immunocompromised patients with and without AIDS: A comparison of clinical features and prognosis. Acta Trop. 2004, 90, 11-16.

7. Carnaúba, D., Jr.; Konishi, C.T.; Petri, V.; Martinez, I.C.P.; Shimizu, L.; Pereira-Chioccola, V.L. Atypical disseminated leishmaniasis similar to post-kala-azar dermal leishmaniasis in a Brazilian AIDS patient infected with Leishmania (Leishmania) infantum chagasi: A case report. Int. J. Infect. Dis. 2009, 13, 504-507.

8. Herwaldt, B.L. Miltefosine — the long-awaited therapy for visceral leishmaniasis? N. Engl. J. Med. 1999, 341, 1840-1842.

9. Carrión, J.; Folgueira, C.; Alonso, C. Immunization strategies against visceral leishmaniosis with the nucleosomal histones of Leishmania infantum encoded in DNA vaccine or pulsed in dendritic cells. Vaccine 2008, 26, 2537-2544.

10. Momeni, A.Z.; Reiszadae, M.R.; Aminjavaheri, M. Treatment of cutaneous leishmaniasis with a combination of allopurinol and low-dose meglumine antimoniate. Int. J. Dermatol. 2002, 41, 441-443.

11. Natera, S.; Machuca, C.; Padrón-Nieves, M.; Romero, A.; Díaz, E.; Ponte-Sucre, A. Leishmania spp.: Proficiency of drug-resistant parasites. Int. J. Antimicrob. Agents 2007, 29, 637-642.

12. Palumbo, E. Current treatment for cutaneous leishmaniasis: A review. Am. J. Ther. 2009, 16, $178-182$.

13. Sims, J.J.; Lin, G.H.Y.; Wing, R.M. Marine natural products: Elatol, a halogenated sesquiterpene alcohol from the red alga Laurencia elata. Tetrahedron Lett. 1974, 39, 3487-3490.

14. König, G.M.; Wright, A.D. Sesquiterpene content of the antibacterial dichlormethane extract of the red alga Laurencia obtusa. Planta Med. 1997, 63, 186-187.

15. Juagdan, E.G.; Kalidindi, R.; Scheuer, P. Two new chamigranes from an hawaiian red alga, Luurenciu cartikzginea. Tetrahedron 1997, 2, 521-528.

16. Vairappan, C.S. Potent antibacterial activity of halogenated metabolites from Malaysian red algae, Laurencia majuscule (Rhodomelaceae, Ceramiales). Biomol. Eng. 2003, 20, 255-259.

17. Lhullier, C.; Donnangelo, A.; Caro, M.; Palermo, J.A.; Horta, P.A.; Falkenberg, M.; Eloir, P.; Schenkel, E.P. Isolation of elatol from Laurencia microcladia and its palatability to the sea urchin Echinometra lucunter. Biochem. Syst. Ecol. 2009, 37, 254-259.

18. Vairappan, C.S.; Anangdan, S.P.; Tan, K.L.; Matsunaga, S. Role of secondary metabolites as defense chemicals against ice-ice disease bacteria in biofouler at carrageenophyte farms. J. Appl. Phycol. 2009, 22, 305-311. 
19. Veiga-Santos, P.; Pelizzaro-Rocha, K.J.; Santos, A.O.; Ueda-Nakamura, T.; Dias-Filho, B.P.; Silva, S.O.; Sudatti, D.B.; Bianco, E.M.; Pereira, R.C.; Nakamura, C.V. In vitro anti-trypanosomal activity of elatol isolated from red seaweed Laurencia dendroidea. Parasitology 2010, 14, 1-10.

20. White, D.E.; Stewart, I.C.; Grubbs, R.H.; Stoltz, B.M. The catalytic asymmetric total synthesis of elatol. J. Am. Chem. Soc. 2008, 23, 810-811.

21. White, D.E.; Stewart, I.C.; Seashore-Ludlow, B.A.; Grubbs, R.H.; Stoltz, B.M. A general enantioselective route to the chamigrene natural product family. Tetrahedron 2010, 26, 4668-4686.

22. Wang, B.; Zhang, W.; Duan, X.; Li, X. In vitro antioxidative activities of extract and semi-purified fractions of the marine red alga, Rhodomela confervoides (Rhodomelaceae). Food Chem. 2009, 113, 1101-1105.

23. Iliopoulou, D.; Roussis, V.; Pannecouque, C.; De Clercq, E.; Vagias, C. Halogenated sesquiterpenes from the red alga Laurencia obtusa. Tetrahedron 2002, 58, 6749-6755.

24. Sudatti, D.B.; Rodrigues, S.V.; Pereira, R.C. Quantitative GC-ECD analysis of halogenated metabolites: Determination of surface and within-thallus elatol of Laurencia obtusa. J. Chem. Ecol. 2006, 32, 835-843.

25. Kladi, M.; Vagias, C.; Stavri, M.; Rahman, M.M.; Gibbons, S.; Roussis, V. C15 acetogenins with antistaphylococcal activity from the red alga Laurencia glandulifera. Phytochem. Lett. 2008, 1, 31-36.

26. Sudatti, D.B.; Rodrigues, S.V.; Coutinho, R.; Gama, B.A.P.; Salgado, L.T.; Amado Filho, G.M.; Pereira, R.C. Transport and defensive role of elatol at the surface of the red seaweed Laurencia obtusa (Ceramiales, Rhodophyta). J. Phycol. 2008, 44, 584-591.

27. Salgado, L.T.; Viana, N.B.; Andrade, L.R.; Leal, R.N.; Gama, B.A.P.; Attias, M.; Pereira, R.C.; Amado Filho, G.M. Intra-cellular storage, transport and exocytosis of halogenated compounds in marine red alga Laurencia obtusa. J. Struct. Biol. 2008, 162, 345-355.

28. Vairappan, C.S.; Suzuki, M.; Abe, T.; Masuda, M. Antibacterial halogenated metabolites from the Malaysian Laurencia species. Phytochemistry 2001, 58, 291-297.

29. Schaeffer, D.J.; Krylov, V.S. Anti-HIV activity of extracts and compounds from algae and cyanobacteria. Ecotoxicol. Environ. Saf. 2000, 45, 208-227.

30. Matsuhiro, B.; Conte, A.F.; Damonte, E.B.; Kolender, A.A.; Matulewicz, M.C.; Mejías, E.G.; Pujol, C.A.; Zúñiga, E.A. Structural analysis and antiviral activity of a sulfated galactan from the red seaweed Schizymenia binderi (Gigartinales, Rhodophyta). Carbohydr. Res. 2005, 340, 2392-2402.

31. Freile-Pelegrin, Y.; Robledo, D.; Chan-Bacab, M.J.; Ortega-Morales, B.O. Antileishmanial properties of tropical marine algae extracts. Fitoterapia 2008, 79, 374-377.

32. Kang, J.Y.; Khan, M.N.A.; Park, N.H.; Cho, J.Y.; Lee, M.C.; Fujii, H.; Hong, Y.K. Antipyretic, analgesic, and anti-inflammatory activities of the seaweed Sargassum fulvellum and Sargassum thunbergii in mice. J. Ethnopharmacol. 2008, 116, 187-190.

33. Moo-Puc, R.; Robledo, D.; Freile-Pelegrin, Y. Evaluation of selected tropical seaweeds for in vitro anti-trichomonal activity. J. Ethnopharmacol. 2008, 120, 92-97. 
34. Mayer, A.M.S.; Rodríguez, A.D.; Berlinck, R.G.S.; Hamann, M.T. Marine pharmacology in 2005-2006: Marine compounds with anthelmintic, antibacterial, anticoagulant, antifungal, anti-inflammatory, antimalarial, antiprotozoal, antituberculosis, and antiviral activities; affecting the cardiovascular, immune and nervous systems, and other miscellaneous mechanisms of action. Biochim. Biophys. Acta 2009, 1790, 283-308.

35. Orhan, I.; Sener, B.; Kaiser, M.; Brun, R.; Tasdemir, D. Inhibitory activity of marine sponge-derived natural products against parasitic protozoa. Mar. Drugs 2010, 15, 47-58.

36. Scala, F.; Fattorusso, E.; Menna, M.; Taglialatela-Scafati, O.; Tierney, M.; Kaiser, M.; Tasdemir, D. Bromopyrrole alkaloids as lead compounds against protozoan parasites. Mar. Drugs 2010, 8, 2162-2174.

37. Lazardi, K.; Urbina, J.A.; Souza, W. Ultrastructural alterations induced by two ergosterol biosynthesis inhibitors, Ketoconazoleand Terbinafine, on epimastigotas and amastigotes of Trypanosoma (Schizotrypanum) cruzi. Antimicrob. Agents Chemother. 1990, 34, 2097-2105.

38. Rodrigues, J.C.F.; Attias, M.; Rodriguez, C.; Urbina, J.A.; Souza, W. Ultrastructural and biochemical alterations induced by 22,26 -Azasterol, a $\Delta^{24(25)}$-Sterol methyltransferase inhibitor, on promastigote and amastigote forms of Leishmania amazonensis. Antimicrob. Agents Chemother. 2002, 46, 487-499.

39. Lorente, O.S.; Rodrigues, J.C.F.; Jiménez, C.J.; Joyce-Menekse, M.; Rodrigues, C.; Croft, S.L.; Yardley, V.; Luca-Fradley, K.; Ruiz-Pérez, L.M.; Urbina, J.; Souza, W.; Pacanowska, D.G.; Gilbert, I.H. Novel azasterols as potential agents for treatment of leishmaniasis and trypanosomiasis. Antimicrob. Agents Chemother. 2004, 48, 487-499.

40. Rodrigues, J.C.F.; Bernardes, C.F.; Visbal, G.; Urbina, J.A.; Vercesi, A.E.; Souza, W. Sterol methenyl transferase inhibitors alter the ultrastructure and function of the Leishmania amazonensis mitochondrion leading to potent growth inhibition. Protist 2007, 158, 447-456.

41. Cassano, V. Taxonomia e filogenia do complexo Laurencia (Ceramiales, Rhodophyta), com ênfase no estado do Rio de Janeiro, Brasil. Ph.D. Thesis, Instituto de Botânica da Secretaria de Estado do Meio Ambiente, São Paulo, Brasil, 2009; p. 328.

42. König, G.M.; Wright, A.D. Laurencia rigida: Chemical investigations of its antifouling dichloromethane extract. J. Nat. Prod. 1997, 60, 967-970.

43. Warren, L.G. Metabolism of Schizotrypanum cruzi Chagas. I. Effect of culture age and substrate concentration on respiratory rate. J. Parasitol. 1960, 46, 529-539.

Samples Availability: Available from the authors.

(C) 2010 by the authors; licensee MDPI, Basel, Switzerland. This article is an open access article distributed under the terms and conditions of the Creative Commons Attribution license (http://creativecommons.org/licenses/by/3.0/). 